\title{
A NEVELÉSLÉLEKTAN A KORAI KÁDÁR-KORSZAKBAN ${ }^{+}$
}

\author{
DARVAI TIBOR
}

ELTE Bárczi Gusztáv Gyógypedagógiai Kar, Általános Gyógypedagógiai Intézet

Az 1950-es évek közepétől kezdve lehetőség nyílt a pszichológia legitim művelésére a Szovjetunióban és az érdekszférájába tartozó országokban, így Magyarországon is. A diszkreditáció megszünése érvényes volt a pszichológia egyik alkalmazott területére, a neveléslélektanra is. E változássorozat egyik elemeként 1956-ot követően az egyetemi-akadémiai mezőben sorra születtek a neveléslélektani kandidátusi disszertációk először a neveléstudomány, majd az 1960-as években már a pszichológia tudományának területén. Ezzel párhuzamosan a hatvanas években létrejött a neveléslélektannak egy másik iránya, mely nem az egyetemi-akadémiai, hanem a föiskolai szférához tartozott. Kutatásunkban e két neveléslélektani irányzat kialakulásának történetét és főbb jellemzőit tárjuk fel.

Kulcsszavak: neveléslélektan, szocialista oktatáspolitika, pedagógia

From the mid-1950s, there was an opportunity to cultivate psychology legitimately in the Soviet Union and in the countries belonging to its sphere of interest, including Hungary. The termination of the discredition was valid for all the psychological fields as well as for educational psychology. As one of the results of this change, after 1956, academic-university level Candidate dissertations were published, one after the other in educational psychology, first in the field of educational science and then in psychology, in the 1960s. At the same time, another direction of educational psychology emerged which belonged not to the academic-university level but to the college sphere. In our research, we will reveal the main features and the history of the development of these two educational psychological directions.

Keywords: educational psychology, socialist educational policy, pedagogy

Levelező szerző: Darvai Tibor, ELTE Bárczi Gusztáv Gyógypedagógiai Kar, Általános Gyógypedagógiai Intézet, 1097 Budapest, Ecseri út 3. E-mail: darvai.tibor@gmail.com

+ Köszönöm Sáska Géza hasznos szakmai észrevételeit, megjegyzéseit. 


\section{Az előzmények: oktatáspolitika, pedagógia és lélektan az 1950-es években}

A z ötvenes évek elejére Magyarországon a sztálinista mintának megfelelően a nyugati irányultságú és nyugati gyökerekkel is rendelkező tudományokat száműzték a tudományos mezőből, a genetikától kezdve a szociológián át a pedológiáig és a lélektanig. A kiszorítás politikai okokban keresendő, még ha egyes esetekben a bírálatoknak lehettek is tárgyi alapjai. A politikai ok a sztálini autarkiában és a hidegháborús helyzetben keresendő. A szovjet mintának a magyar oktatási mezőre történő implementációja során az 1950-es párthatározat diszkreditálta a pedológiát és lélektant az oktatás és a tudomány területéről (Kardos-Kornidesz 1990). A magyar párthatározat az 1936-os szovjet pedológiaellenes párthatározat forgatókönyvét és érvkészletét vette át (Péter 1954).

Az oktatáspolitikai határozat bírálta az Ortutay Gyula által vezetett Vallás- és Közoktatásügyi Minsztériumot és a gyermekpszichológus, pedológus Mérei Ferenc által irányított Országos Neveléstudományi Intézetet (ONI). A párthatározat implementációja során ez előbbit átszervezték (Kardos-Kornidesz 1990), utóbbit pedig meg is szüntették. Mérei és köre parkolópályára, az ONI Didaktikai Tanszékét vezető Kiss Árpád pedig Kistarcsára, internálótáborba került. A párthatározat Méreiéket tette felelőssé a tankönyvkiadás zavaraiért, a pedagógusképzés szakmai-ideológiai hibáiért, a munkásparaszt származású gyermekek magas iskolai lemorzsolódási arányáért és a nyugati, burzsoá befolyásért is (Kardos-Kornidesz 1990). A párthatározatot megelőző februári pártközponti jelentés az ONI személyi összetételéről, korabeli szóhasználattal káderhelyzetéről, a következőt állította: „Rohadt kispolgári klikket szervezett maga köré, melyet szöröstöl-böröstöl átvett a régi pszichológiai »munkaközösségböl«." (Kardos-Kornidesz 1990: 374.)

A pedológusok által használt tesztmódszertant (Carson 2014; Leopoldoff 2014) erőteljesen opponálta az 1936-os sztálini politika (Péter 1954), míg a magyar határozatból ez teljesen hiányzott. Nem tartalmazta a magyar dokumentum a fogyatékos gyermekek külön iskolába való áthelyezésének hibáját (Péter 1954). Ennek egyik lehetséges magyarázata az lehet, hogy a Szovjetunióban sokkal hosszabb idő állt a pedológia híveinek rendelkezésére, rendszerük kiépülhetett, nem úgy, mint Magyarországon. Közismert, hogy a pedológián alapult a Szovjetunió állami oktatáspolitikája már 1917-től. Magyarországon azonban csupán a kommunista hatalomátvételt követően az 1948-ban alapított ONI képviselte intézményes állami politikaként a pedológiai nézőpontot.

$\mathrm{A} z$ oktatási párthatározat hatására a gyermekközpontú pedológiát felváltotta az államközpontú szocialista pedagógia (Sáska 2015). Ugyanúgy, ahogyan az 1936-os pedológiai határozat visszahelyezte jogaiba a szocialista pedagógiát és a neveléstudományt a nyugat orientációjú pedagógusokkal és analitikus pszichológusokkal szemben (Ewing 2001). A szocialista neveléstudományban - talán - a didaktika lett a legfontosabb terület (Sáska 2009). Az új szocialista irányultságú neveléstudomány monopolhelyzetbe került, cserébe viszont megkapta a totális politikai kontrollt.

A diszkreditált tudományok számára Magyarországon a kedvező pillanat három évvel Sztálin halála után, 1956-ban jött el. 1956 februárjában a hatalmi erőviszonyok (ismét) megváltoztak a Kremlben, s Hruscsovnak sikerült legyőznie ellenfeleit. E po- 
litikai fordulatról tanúskodik Hruscsov híres-hírhedt, a sztálini rendszer büneit leleplező beszéde az SZKP XX. kongresszusán. A kongresszuson Hruscsov antisztálinista politikát hirdetett az állami rendszer minden szegmensében, s e gyökeres változás az oktatási és a tudományos mezőt sem hagyhatta érintetlenül. A desztalinizáció a lélektant is érintette. A lélektan száműzetése megszünt, a „sztálini fogság” véget ért, és lehetőség kínálkozott a politika által kijelölt határok között a pszichológia intézményesülésére.

$\mathrm{A} z$ új antisztálinista politikát a szovjet neveléstudomány sztálinista szereplői fordították le a pedagógia nyelvére. Ennek az egyik fontos indikátora a Szovjetszkaja Pedagogika 1956-os 8. száma, amelyben megjelent az új szovjet oktatáspolitika iránydokumentuma, a Sokrétüen és alaposan tanulmányozzuk a gyermeket címet viselő anyag. A közlemény Pedagógiai Szemlében ${ }^{1}$ közölt fordítása szerint az újértelmezett szocialista, de antisztálinista neveléstudománynak vissza kell hoznia a gyermeket a pedagógiába (Sz. N. 1957). E mozzanatról így referált az iránymutató közleményः „Neveléstudományunknak ezért határozattan át kell alakulnia, valóban fel kell vérteznie magát a gyermekek életkori sajátosságainak ismeretével, egyéni sajátságaik alapos megértésével, valamint az ember lelki, pszichikai fejlödésére, egyéniségének kialakulására vonatkozó, behatóan kidolgozott marxista elmélettel." (Sz. N. 1957: 14.)

A nyitás mértékét mutatja, hogy noha a pedológiát és annak tesztmódszerét továbbra is helytelennek tartotta az állásfoglalás, azonban károsnak tekintette, hogy a pedológiával együtt számüzték a gyermekek pszichológiai tanulmányozását is, s a „pszichofóbia” légkörét hozták létre (Sz. N. 1957). Az új kurzus lehetőséget nyitott a újraértelmezett marxista, azaz nem polgári pszichológia müvelésére. Az új korszak emblematikus pszichológusa, a sztálini korszakban ünnepelt, majd félreállított Rubinstein lett, ezzel is jelezve az újradefiniált és egyben desztalinizált pszichológia létjogosultságát.

1957-ben az Akadémia II. Osztályán belül létrejött a Lélektani Bizottság, amelynek neve 1958-ban Pszichológiai Bizottságra változott. 1958-ban az Akadémia gondozásában elindult az évenként megjelenő sorozat, a Pszichológiai Tanulmányok, majd 1960-tól kezdve újra megjelent a Magyar Pszichológiai Szemle (Kovai 2016). A pszichológiában bekövetkező változásokat érdemes összevetni a neveléstudományban történt változásokkal. A pszichológiához hasonlóan szintén 1958-tól jelent meg, szintén az Akadémiai Kiadó gondozásában az évenként megjelenő Tanulmányok a neveléstudományból c. sorozat, 1961-ben pedig újraindult a Magyar Pedagógia. A két tudományban lévő szinkronitás aligha lehet a véletlen műve.

A hatvanas években a Moszkvai és a Leningrádi Egyetemen is önálló pszichológiai tanszék jött létre (Kozulin 1989), Magyaroszágon ugyanebben az időszakban, 1963-ban az ELTE-n is megindult az önálló pszichológusképzés (Kovai 2016). A pszichológia újraintézményesülésének fontos állomásaként, felszámolása után tíz évvel, 1958-ban megalakult a Magyar Pszichológiai Társaság (MPT) (Hunyady 2004).

A hatvanas évek elején mindössze egy kis kör müvelte a pszichológiát és a pszichológus szerep mindig is rendelkezett ellenzéki mozzanattal, a szocialista környezetben

A Sokrétüen és alaposan tanulmányozzuk a gyermeket címü közlemény az 1957-es Pedagógiai Szemle első számában jelent meg. E lapszám volt az 1956-os októberi forradalom után megjelent első Pedagógiai Szemle. E helyen a magyar fordításra hivatkozom. 
(Pléh 2016), ám a pszichológia tudománya a diszkreditációtól eljutott az intézményesülésig.

\section{A neveléslélektan egyetemi-akadémiai szinten}

A neveléslélektan egyetemi-akadémiai iránya a kandidátusok és az akadémiai doktorok segítségével is leírható. A szovjet mintát követve a felsőoktatásban a tudományos minősítés rendszerét az ötvenes évek elején átszervezték, és a tudományos minősítés hatásköre az egyetemektől az MTA-n belül müködő Tudományos Minősítő Bizottsághoz került. A tudományos minősítés megléte a felsőoktatási alkalmazás és a tudományos karrier feltételei közé tartozott. Ebből következik, hogy a szocialista korszakban a kandidátusok és az akadémiai doktorok számának alakulása jól mutatja egy-egy tudomány intézményesülésének fokát és pozícióját az egyetemi-akadémiai mezőben (Brezsnyánszky 2015; Karády 2015; Pénzes 2013; Sáska 2016).

Mivel a neveléslélektan egyaránt érinti a pedagógia és a pszichológia diszciplínáját, ezért a neveléstudományon belül a lélektani területtel, a pszichológia területén belül a pedagógiával foglalkozó kandidátusok és akadémiai doktorok számának alakulását vizsgáltuk meg. Forrásként a hatvanas években megjelent Akadémiai Almanachokat használtuk fel (Almanach 1962, 1967, 1970, 1973). Az Almanachok a Magyar Tudományos Akadémia kiadásában jelentek meg, ezért ezekre a szocialista tudomány állásáról hüen referáló dokumentumokként tekintettünk.

Meg kell jegyeznünk, hogy vizsgált korszakunkban a tudományterületi besorolások igencsak képlékenyek voltak, ami abból is látszik, hogy néhány minősített esetében az egyes almanachok más és más diszciplínát közöltek. Ezért kellett az almanachok kategorizációja mellett a tudományos életút irányára és tartalmára is hagyatkoznunk. Ennek során a Pedagógiai Lexikonokat használtuk fel (Báthory-Falus 1997; Nagy 19761979).

A neveléslélektan egyetemi-akadémiai szálának első megjelenése 1956-1957-re tehető. Hiszen 1957 előtt pszichológiából egyáltalán nem, csakis neveléstudományból lehetett tudományos fokozatot szerezni. Ez egyben azt is jelentette, hogy a neveléstudomány azon kandidátusai, akik lélektani területre tartozó témában védték meg diszszertációjukat 1956-1957-et követően kérésükre tudományos címük területét neveléstudományról pszichológiára változtathatták. ${ }^{2}$

1962-ben a neveléstudomány területén 18 kandidátussal rendelkező személy tevékenykedett, ebből 6 személy foglalkozott neveléslélektannal az Akadémiai Almanch szerint: Baranyai Erzsébet, Várkonyi Dezső, Bartha Lajos, Duró Lajos, Kelemen László és Salamon Jenő (Almanach 1962). E csoportot két részre bonthatjuk: a "régiekre”, akik már 1956-1957 előtt is pszichológusok voltak: Baranyai Erzsébet, Várkonyi Dezső; és az „újakra”, akik 1956-1957-et követően váltak neveléspszichológussá: Bartha Lajos, Duró Lajos, Kelemen László, Salamon Jenő. Közülük hárman a kandidátusi címüket a Szovjetunióban védték meg (Bartha Lajos, Duró Lajos, Salamon Jenő). A Szovjetunióban megszerzett kandidátusi fokozatot a szovjet típusú szocializmushoz való lojalitás releváns indikátoraként értelmezzük. E mozzanatból is látható, hogy milyen erős még a szovjet szál az újonnan rekrutálódott neveléspszichológusok esetében. Érdemes meg-

\footnotetext{
2 Ilyen kutató volt például Geréb György.
} 
jegyezni, hogy ekkor még Kardos Lajos a neveléstudománynak és nem a pszichológiának volt az akadémiai doktora.

1962-ben a pszichológiának csupán négy kandidátusa volt, közülük Geréb György és Lénárd Ferenc foglalkozott neveléslélektannal (Almanach 1962). Kutatásunk szempontjából viszont igencsak releváns, hogy már 1962-ben is találhatók neveléspszichológiával foglalkozó kutatók az intézményesült pszichológiában.

1970-re a neveléstudományi területen - a témától függetlenül - a kandidátusok száma 18-ról (1962) 46-ra növekedett, s ebből mindössze hárman foglalkoztak neveléslélektannal (vö. 1962-ben 6-an): Baranyai Erzsébet, Várkonyi Dezső és Pataki Ferenc. Ha jól megvizsgáljuk e három személyt, akkor az akár egy före is redukálható, Pataki Ferencre. Hiszen Baranyai Erzsébet és Várkonyi Dezső még a 19. század végén születtek és már régen elérték a nyugdíjkorhatárt. Emellett 1970-ben a neveléstudomány három akadémiai doktorral rendelkezett - Földes Éva, Nagy Sándor, Szarka József -, s egyikőjük sem foglalkozott neveléslélektannal.

1970-re a Pszichológiai Bizottság előtt védett kandidátusok száma az 1962-es négyről 24 före emelkedett, közülük 11-en foglalkoztak neveléslélektannal (Almanach 1970). Ami nemcsak azt jelenti, hogy összességében hatszorosára növekedett a pszichológiai kandidátusok száma - a neveléstudomány esetében ez csak két és félszeres -, hanem azt is, hogy majdnem minden második pszichológiai kandidátus foglalkozott neveléslélektannal, az intézményes neveléstudomány szervezeti hálózatán kívül, mondhatjuk úgy is, hogy az akadémiai mérce szerint a neveléstudomány ennyit veszített (Darvai 2019). Aminek egyik jelentős oka, hogy a hatvanas években a neveléslélektan felé tájékozódó fiatal korosztály tagjai nem a neveléstudományt, hanem a pszichológiát választották, majd a hatvanas évek közepén, végén védték meg kandidátusi disszertációjukat. ${ }^{3}$

A z 1970-es akadémiai almanach szerint a pszichológia tudományának területén négy akadémiai doktor tevékenykedett: Bartha Lajos, Horváth László Gábor, Kardos Lajos és Kelemen László (Almanach 1970). Közülük Bartha és Kelemen a neveléstudomány területén kandidátusi címüket neveléslélektanból szerezték meg, azonban 1970-ben már a pszichológia területén lettek az akadémia doktorai (Almanach 1970). $\mathrm{A} z$ akadémiai doktor címek példája is megerősíti korábbi érvelésünket, mely szerint a neveléslélektan a tudományos minősítések szempontjából már nem a neveléstudomány területén, hanem a pszichológiában vált hangsúlyosabbá.

A Kádár-korszakban a pszichológusok hagyományosan a nyugati iskolázottságú és irányultságú kutatók voltak, s 1956 után a részlegesen rehabilitált pszichológusok ellenzéki attitűdje e foglalkozás egészére kivetült (Pléb 1998a). A neveléslélektani kutatók - Lénárd Ferenc kivételével - nem ebből a körből kerültek ki. Tudományos habitusokat tekintve a keleti, a szovjet irányultságot képviselték a pszichológiában, ahol nevezzük itt így „az államszocialista pszichológiát” tanulták, s Szovjetunióban szerezték meg a honosított kandidátusi fokozatukat, mint Salamon Jenő, aki az ELTE-n lesz a fejlődéslélektani és neveléslélektani intézet vezetője, Duró Lajos, a szegedi egyetemen, Kelemen László pedig a pécsi, majd a debreceni egyetemen kap tanszéket.

A két egymástól alapvetően eltérő iskolázottságú és szellemű csoport intézményesen is elkülönült, de csak Budapesten. Az ELTE-n, a Salamon Jenő vezette fejlődés- és neveléslélektani tanszékkel szemben, a Barkóczi Ilona nevével fémjelzett általános lé-

Többek között Rókusfalvy Pál is. 
lektani tanszéket nevezték a hallgatók „A Tanszéknek” (Pléh 2016). Hunyady György véleménye szerint a két tanszék jellege abban különbözik, hogy: „... egy a nyugati, egy a keleti szakmai orientációnak, egy az informális, egy a formális pártállami befolyásnak” (Hunyady 1996: 9) szólt. Az ELTE neveléstudományi képviselői a keleti orientációjú és formális pártállami befolyást élvező körrel találták meg a hangot.

Más egyetemi városokban azonban a szovjet eredetű neveléstudományi és pszichológiai felfogásnak, hosszú ideig nem volt személyi és szervezeti alternatívája.

A keleti pszichológiai felfogású és szocialista irányultságú neveléslélektani oktatókkutatók közötti összhangot bizonyítja, hogy megtalálhatjuk őket a korszak legrangosabb hazai neveléstudományi periodikáinak - Magyar Pedagógia, Pedagógiai Szemle -, továbbá a Tanulmányok a neveléstudomány köréböl és a Pszichológiai tanulmányok kötetek szerzői, szerkesztői és szerkesztőbizottsági tagjai között.

\section{A neveléslélektan megjelenése a pedagógiai főiskolákon}

Az immár legitim lélektani szóhasználatú érvelés fokozatosan terjedt el az egyetemiakadémiai szférában, és az oktatásügyi-oktatáspolitikai mezöben is, többek között a pedagógusképzésben, különösképpen a tanítóképzői szférában.

Egyik jellegzetessége abból fakadt, hogy a Művelődésügyi Minisztérium egy osztálya is csatlakozott és igyekezett koordinálni e sajátos jellemzőkkel rendelkező neveléslélektani irányt. Szempontunkból a minisztériumi mozzanat azért is releváns, mert az ötvenes években az igencsak elképzelhetetlennek tünt, hogy a számüzött lélektan egyik ága nemcsak, hogy legitim oktatásügyi iránnyá szerveződjön, és képviselhesse érdekeit-értékeit az oktatásügyi mezőben, de még a Művelődésügyi Minisztérium támogatását is élvezze. A hatvanas években azonban annyit változott a világ, hogy ez megtörténhetett, legitim módon.

A főiskolai neveléslélektani irányzat szervező, központi intézménye az oktatásirányítás egyik legfőbb szervéhez a Művelődésügyi Minisztériumhoz kapcsolható. 1966ban a Müvelődésügyi Minisztériumon belül létrejött a Pedagógusképzés Önálló Osztálya, Miklósvári Sándor vezetésével. ${ }^{4} \mathrm{~A} z$ osztály feladata a pedagógus képzési terület koordinálása lett. A minisztériumi osztály vezetöje az alábbi módon fogalmazta meg oktatásirányitói szerepkörét: „... közoktatáspolitikánknak megfelelöen és azzal összhangban gondoskodjék az általános iskolai, a gyógypedagógiai és az óvodai pedagógusképzésröl, irányítsa és ellenőrizze a tanárképzö föiskolák, a tanitó- és óvónöképzö intézetek munkáját." (Sz. N. 1966: 492.)

A minisztériumi osztály a minisztérium két lapjában - a Köznevelésben és a Tanitóban - megjelenő és neveléslélektani érvelést használó főiskolai oktatók közötti összhang megteremtésére törekedett, és egységes nézetet képviselő csoporttá szervezte őket. Ebben élen járt az említett minisztériumi osztályvezető, aki az 1960-as évek második felétől a Tanitó és a Köznevelés szerkesztőségeinek befolyásos tagja volt. Ugyanő irányította a tanítóképzők oktatóira támaszkodó pedagógusképzési- és továbbképzési szervezeti egységet, a Tanítók Akadémiáját.

4 Miklósvári Sándor az 1961-es oktatási reform - melynek fontos eleme az 5+1 oktatás bevezetése a gimnáziumokban (5 nap tanulás és 1 nap munka) - embere, oktatáspolitikai támogatója és megvalósítója. Miklósvári Sándor szerkesztette az 1962-ben megjelent Nevelési tervet (Miklósvári 1962). Miklósvári 1976-1980 között az Országos Pedagógiai Intézet (OPI) igazgatója volt, Szarka Józsefet követve. 
Magyarországon ekkor 10 tanítóképző intézet működött, s közülük hatban képviselték a lélektani, neveléslélektani szempontokat. A Köznevelésben és a Tanitóban megjelent publikációk szerzőinek, valamint a Tanítók Akadémiája résztvevőinek nevei alapján azonosítható, hogy a debreceni, a bajai, a nyíregyházi, a jászberényi, az esztergomi és a kaposvári tanítóképzőkről van szó. E körhöz tartozott még a szegedi tanárképző föiskola is. ${ }^{5}$

$\mathrm{A} z$ említett minisztériumi lapok témáinak koordinációja és tartalmának irányított szakmaisága a hruscsovi politikát követő 1961-es oktatási törvény céljaihoz és szelleméhez igazodott. A hivatalos pszichológia, s benne a Kelet, illetve az államszocializmus felé tájékozódó neveléslélektani érvrendszer az iskolareformot ${ }^{6}$ teljes mellszélességgel támogatta, s ezáltal új és nagyobb tér is nyílt előttük a szakmai közéletben és a főiskolai és egyetemi szintű pedagógusképzésben. Az állami célokat képviselő minisztériumtól való függés következménye, hogy a felépülő szocialista neveléslélektani koncepció a minisztériumi politika része lett, s így a posztsztálini állami politika gyakorlata és a neveléslélektani felfogás egymást feltételezve egyidőben olyképpen épült ki, hogy a lélektan képviselői követték az állami célokat, és alávetették magukat az állami irányításnak.

Miklósvári Sándor, a Pedagógusképzés Önálló Osztályának vezetője először a Köznevelés hasábjain jelölte meg az alkalmazott neveléslélektan hatáskörét. Kifejtette, hogy nemcsak a pedagógiai, hanem a lélektani szemléletmódnak is helye van a törvény sikeres végrehajtását támogató, újjászervezett pedagógusképzésben (Sz. N. 1966). A minisztériumi osztályvezető ugyanezt erősítette meg egy évvel később a Köznevelésben (Miklósvári 1967a).

$\mathrm{A} z$ új szervezésű neveléslélektan a pedagógus-továbbképzés célját a sztálini időszak neveléstudományának meghaladásában jelölte ki, mint állítja: „A pedagógiai dogmatizmus még élö maradványait és ennek a gyakorlatban még tapasztalbató jelenségeit itélik el a korszerü [pedagógiai, lélektani és didaktikai - D. T. megjegyzése] szemlélettel [a továbbképzésen elhangzó] előadások." (Miklósvári 1967b: 591.) E program e neveléslélektan legitimálásának megerősítését jelenti. Egyben a tudományon és az iskolán belül a politikai-ideológiai harc szakmai eszköze a lélektani tudás lett.

Fábián Zoltán, a jászberényi tanítóképző pszichológus oktatója a neveléspszichológia kormányzati hasznosítását említi cikkében. Megítélése szerint a lélektani megközelítés akkor és azért szükséges „... ha az új tanterv és nevelési terv követelményeit, az iskolareform célkitüzéseit eredményesen akarjuk megvalósítani" (Fábián 1964: 4). Magyarán, a neveléslélektannak a makroszintü oktatáspolitika termékeinek - központi tervek, nevelési terv, tanterv - mikroszintü implementálásában rejlik elsődleges szerepe. Azaz: végrehajt.

A kor jellegzetes, csupán makroszinten érvényes gondolkodás- és érvelési módjával élt a jászberényi tanítóképző oktatója. Különösen érdekes, hogy a homogén tulajdonságokkal felruházott valamennyi „gyermek” az egyforma szociális összetételü iskolával és

5 A szegedi tanárképző főiskola Hegedűs András okán tartozik ide, ugyanis Hegedűs András 1968-ig a Bajai Tanítóképző igazgatója volt, majd 1968-tól a szegedi Juhász Gyula Tanárképző Főiskola tanszékvezető főiskolai tanára és a főiskola főigazgatója lett. Hegedűs „vitte magával” pedagógiai-lélektani koncepcióját Szegedre.

6 Az 1961-es oktatási reform egyik legfontosabb eleméről, a gyakorlati foglalkozásról lásd: Somogyvári 2015; a reform továbbéléséhez pedig: Darvai 2016. 
az ugyanolyan felkészültségű pedagógussal került azonos helyzetbe, amelyben a szakértő az alábbi értékviszonyokat és teendőket látja:

„A pedagógus... a tanulók megismerését nem öncélúan, hanem a nevelömunka érdekében végezzük. [Köztudott, hogy a pedagógia itt, a »gyermek tanulmányozásánál« lényegében megállt.] Az elöbbi séma - viselkedés-tulajdonság-várható viselkedés - munkánk lélektani tudatositásának csupán egyik összetevője. A másik: a gyermek fejlesztésének, nevelésének az elemzése. Lélektani szempontból ugyanis a nevelés bonyolult folyamatát - nagyon leegyszerüsitve - igy lebet jellemezni: amikor már elöre látjuk, bogy a gyermektöl milyen viselkedés várható, ezt összehasonlitjuk a nevelési feladatainkban rögzitett kivánt viselkedéssel és teljesitménnyel; illetve a gyermek meglévő tulajdonságait a kivánt tulajdonságokkal. Attól függően, hogy életkoronként és egyénenként milyen fokú ez az eltérés az embereszmény, $s$ a valóságos helyzet között, aszerint kell megválasztani nevelési eljárásainkat. Ez megint nagyfokú pedagógiai és lélektani tudatosságot kiván meg, biszen egy adott tulajdonságot nem lebet akárminő eljárással kialakítani. Ez az a másik kritikus pont, abol a lélektan ismét sokat segitheti a gyakorlati nevelömunkát." (Fábián 1964: 4-5 - kiemelés D. T.)

$\mathrm{A} z$ idézett, új neveléslélektani gondolkodás intellektuális hátterének forrását talán meg is találtuk. Fábián Zoltán neveléslélektani szóhasználata egybeesik a már említett, a posztsztálinizmus jelentését és határait kijelölő Sokrétüen és alaposan tanulmányozzuk a gyermeket (Sz. N. 1957) c. szovjet dokumentumban közöltekével. A Fábián-féle föiskolai lélektan szakmaisága Magyarországon az ötvenes évek közepén Moszkvában kijelölt értelmezési rendszer keretei között bontakozhatott ki. A keleti minta követése épp olyan erős volt itt is, mint ahogyan azt az egyetemi-akadémiai neveléslélektan esetében már láttuk.

A fenti idézet utolsó mondata a pedagógia és a (nevelés)lélektan közötti hierarchikus viszonyt érinti. A lélektan nemcsak az oktatáspolitika irányának, hanem a pedagógiának is alá van vetve.

Ugyanehhez a föiskolai csoporthoz tartozott Kiss Lajos, a debreceni tanítóképző oktatója is. Kiss az 1961-es iskolareform egyik elemeként bevezetett környezetismeret tantárgy tanításának pszichológiai szempontjairól írt (Kiss 1972). Kiss cikke nemcsak oktatáspolitikai, hanem lélektani szempontból is releváns, ugyanis megjelenik az aktivitás problematikája, ami a harmincas évektől a szovjet pszichológia egyik megosztó politikai és szakmai eleme volt, amelyből a posztsztálini időszakban egy „köztes” elméletet tekintettek hivatalosan marxistának, amit a nagyhatású Rubinstein (1967) képviselt. Eszerint a „külsö hatások a belsö feltételeken keresztül érvényesülnek” (Pléb 19986). Ezt a hely hiányában nem részletezhető "köztes” elképzelést képviselte Kiss Lajos is (Kiss 1972). Rendszerében a külső hatás a környezetismeret tantárgyat jelentette. A tanítás-tanulás folyamatának pedig a gyermek jellemzőin, motivációján kellett alapulnia, ahogy írja:

„A gyermek azonban nemcsak külső irányitással fejlödik, hanem önvezérléssel, önszabályozással is rendelkezik, belső késztető erők mozgatják, lökik, lendítik elöre. [...] Hogy a megismerés, a tanulás ne egyszerü passzív benyomási-felvétel legyen, hanem cselekvő, aktív, a személyiséget továbbfejlesztő folyamat, a belső motivációs tényezők müködésbe hozására is gondolnunk kell. Ma már világos, hogy a pedagógiának rendkivül fontos problémája ezeknek a belsö erőknek a felhasználása, hasznos munkába fogása. Ez a motiváció és a motiválás problémája." (Kiss 1972: 4 - eredeti kiemelés.) 
A fenti kijelentés voltaképpen pszichológiai nyelven megfogalmazott pedagógiai értékállítás, amely leginkább a pszichológia helyzetéről, képviselőinek közgondolkodást befolyásoló erejéről referál. E szakmai elképzelés a politikum, az állami ideológia szférájából ered, és a pedagógusképzés területén oktatók szakmai elképzeléssé formáltak. A $z$ aktívabb ember- és gyermekkép képviselete nemcsak a sztálini mintakövető iskolakép alternatívája, hanem kiállás az egységes és általános iskola felső tagozatának nép-, illetve a polgári iskolai, valamint a gimnáziumi elegyes értékrendje közül a háború előtti, a polgári iskolai tanárképzés (Várkonyi Hildebrand felfogását tükröző Cselekvés Iskolája, a reformpedagógia) mellett. A szovjet antisztálinista mintának megfelelően az aktivitás témaköre az új főiskolai neveléslélektani irányzat olyan szakmai elképzelésévé vált, amely ideologikus jegyekkel is rendelkezett, s amelynek a kidolgozását az egyetemi-akadémiai mezőben a pedagógia és a neveléslélektan terén végezték el (Salamon Jenő az ELTE-n és az Országos Pedagógiai Intézetben (Szokolszky 1961), s melyet a Minisztérium képviselt és terjesztett sikerrel.

\section{IRODALOM}

Akadémiai Almanach $(1962,1967,1970,1973)$ A Magyar Tudományos Akadémia Almanachja. Budapest, Akadémiai Kiadó.

Báthory Z. \& Falus I. (1997, eds) Pedagógiai Lexikon I-III. Budapest, Keraban.

Bıró Zs. \& NAGY P. T. (2018) Az oktatáskutatás inter- és multidiszciplináris jellege. Educatio, Vol. 28. No. 1. pp. 84-100.

BrezSNYÁnSZKy L. (2015) Kontinuitás és diszkontinuitás a debreceni egyetem pedagógia oktatóinak rekrutációjában 1940-1970. In: Németr A., Biró Zs. \& Garai I. (eds) Neveléstudomány és tudományos elit a 20. század második felében. Budapest, Gondolat Kiadó. pp. 225-251.

Carson, J. (2014) Mental Testing in the Early Twentieth Century: Internationalizing the Mental Testing Story. History of Psychology, Vol. 17. No. 3. pp. 249-255.

Darvai T. (2016) Szakmai-politikai nézetek és ideológiák az V. Nevelésügyi Kongresszuson. Neveléstudomány, Vol. 4. No. 3. pp. 49-61.

Darvai T. (2019) A szocialista neveléslélektan megteremtése Magyarországon az 1960-as években. Iskolakultúra, Vol. 29. No. 8. pp. 47-67.

Ewing, E. T. (2001) Restoring Teachers to Their Rights: Soviet Education and the 1936. Denunciation of Pedology. History of Education Quarterly, Vol. 41. No. 4. pp. 471-493.

Fábián Z. (1964) Tanítványaink megismeréséről. A Tanitó munkája, Vol. 2. No. 1. pp. 4-6.

Hunyady Gy. (1996) A budapesti tudományegyetem és a pszichológia. Magyar Pszichológiai Szemle, Vol. 52. Nos 1-3. pp. 3-16.

Hunyady Gy. (2004) 75 éves a Magyar Pszichológiai Társaság. Magyar Pszichológiai Szemle, Vol. 59. No. 2. pp. 175-188.

KARÁdy V. (2015) Egy szocialista értelmiségi „államnemesség”? Kandidátusok és akadémiai doktorok a hazai társadalomtudományokban. In: Németh A., Biró Zs. \& GaraI I. (eds) Neveléstudomány és tudományos elit a 20. század második felében. Budapest, Gondolat Kiadó. pp. 251-281.

Kardos J. \& Kornidesz M. (1990, eds) Dokumentumok az oktatáspolitika történetéböl. 1-2. kötet. 1950-1972. Tankönyvkiadó, Budapest.

Kiss L. (1972) Pszichológiai nézőpont a környezetismeret tanításában. A Tanitó, Vol. 10. No. 10. pp. 3-5. 
Kovar M. (2016) Lélektan és politika: pszichotudományok a magyarországi államszocializmusban, 1945-1970. Budapest, KRE-L'Harmattan.

Kozulin, A. (1989) The Changing Face of Soviet Psychology. Studies in Soviet Thought, Vol. 37. No. 3. pp. 185-189.

Leopoldoff, I. (2014) A Psychology for Pedagogy: Intelligence Testing in USSR in the 1920s. History of Psychology, Vol. 17. No. 3. pp. 187-205.

Miklósvári S. (1962, eds) Nevelési Terv. Tankönyvkiadó, Budapest.

Miklósvári S. (1967a) A pedagógusképzés jövője. Köznevelés, Vol. 23. Nos 13-14. pp. 487-489.

Miklósvári S. (1967b) A Tanítók Nyári Akadémiája, 1967. Köznevelés, Vol. 5. Nos 1516. pp. 590-591.

Nagy S. (1976, 1977, 1978, 1979, ed.) Pedagógiai Lexikon I-IV. Budapest, Akadémiai Kiadó.

PÉnzes D. (2013) A tudományos fokozatszerzés átalakulása 1948-1953 között Magyarországon. In: Bask a G., Hegedüs J. \& Nóвıк A. (eds) A neveléstörténet változó arcai. Budapest, ELTE Eötvös Kiadó. pp. 69-80.

Péter A. (1954, ed.) Az SzKP, a Szovjet Kormány és a Komszomol határozatai a szovjet iskoláról. Budapest, Tankönyvkiadó.

Plé Cs. (1998a) A pszichológia szimbolikája egy slampos totalitárius rendszerben. A magyar pszichológia a hatvanas években. In: PléH Cs. (ed.) Hagyomány és újitás a pszichológiában. Budapest, Balassi Kiadó. pp. 91-111.

PléH Cs. (1998b) Pszichológia, szimbolika, diktatúra. Buksz, Vol. 10. No. 3. pp. 288-291.

PLÉH Cs. (2016) Intézmények, eszmék és sorsok a magyar pszichológia fél évszázadában 1960-2010. Magyar Pszichológiai Szemle, Vol. 71. Nos 4-5. 691-723.

Rubinstein, Sz. L. (1967) Lét és tudat. Budapest, Kossuth Kiadó.

SÁska G. (2009): A szocialista neveléstudomány kialakulása és függősorba süllyedése - a didaktika példáján. In: Németr A. \& Biró Zs. H. (eds) A magyar neveléstudomány a XX. század második felében. Budapest, Gondolat Kiadó. pp. 98-130.

SÁska G. (2015) A pedagógiai normák változása az 1920-as 30-as évek Szovjet-Oroszországában. Pedagógiatörténeti Szemle, Vol. 1. No. 1. pp. 31-52.

SÁska G. (2016) A szocialista neveléstudomány rekrutációja 1956-1962 között. In: TóTH P. \& Holık I. (eds) Új kutatások a neveléstudományokban 2015. Pedagógusok, tanulók, iskolák - az értékformálás, az értékközvetítés és az értékteremtés világa. Budapest, ELTE Eötvös Kiadó. pp. 255-262.

Somogyvári L. (2015) A gyakorlati foglalkozás bevezetése az általános iskolában (19581965). Educatio, Vol. 24. No. 4. pp. 79-90.

Sz. N. (1957) Sokrétủen és alaposan tanulmányozzuk a gyermeket. Pedagógiai Szemle, Vol. 7. No. 1. pp. 8-14.

Sz. N. (1966) Napirenden az általános iskolai pedagógusképzés. Köznevelés, Vol. 22. Nos 13-14. pp. 492-493.

Szoкоцszky I. (1961, ed.) Tanulmányok a tanulói aktivitás köréböl. Budapest, Tankönyvkiadó.

A cikk a Creative Commons Attribution 4.0 International License (https://creativecommons.org/licenses/ by/4.0/) feltételei szerint publikált Open Access közlemény, melynek szellemében a cikk bármilyen médiumban szabadon felhasználható, megosztható és újraközölhető, feltéve, hogy az eredeti szerző és a közlés helye, illetve a CC License linkje és az esetlegesen végrehajtott módosítások feltüntetésre kerülnek. (SID_1) 